\title{
Students' Civic Disposition through Learning Civics and Pedagogical Competences of High School Teachers
}

\author{
Apeles L. Lonto \\ Faculty of Social Sciences, Universitas Negeri Manado, Indonesia \\ Received August 23, 2019; Revised November 24, 2019; Accepted December 3, 2019
}

Copyright@2019 by authors, all rights reserved. Authors agree that this article remains permanently open access under the terms of the Creative Commons Attribution License 4.0 International License

\begin{abstract}
This paper contains research on the influence of Civics teaching and pedagogical competence of teachers to the development of students' civic dispositions. The main problem in this research is: Do Civics learning and pedagogical competence of teachers influence the development of civic dispositions of students in SMA Negeri 1 Kawangkoan? The data were obtained through a questionnaire distributed to 60 students. This research also involves data collection and analysis of quantitative data. The study found that: First, Civics Learning has positive influence on Civic disposition of Students in SMAN 1 Kawangkoan which means that through civics learning students could develop their Civic Dispositions. Second, teachers' pedagogic competence has positive effect on Civic disposition of students SMAN 1 Kawangkoan. It means that the better the pedagogical competence of teachers is, the higher the students' Civic dispositions are. Third, Civics Learning and pedagogical competence of teachers jointly have positive effect on Civic dispositions Students SMAN 1 Kawangkoan. It means that through Civics teaching materials studied by students and pedagogical competence of teachers, Civic disposition of students is higher. Thus, this study recommends further research on other civic competences.
\end{abstract}

Keywords Civic Disposition, Learning Civics, Pedagogical Competence, Teachers

\section{Introduction}

The problem on the national character in Indonesia has become the public attention since it is presumed that various problems which the Indonesian people face nowadays are rooted in this matter. Realizing the urgency of this problem, the government has reinforced the necessity of the character-building education since the past few years. The
Ministry of Education and Culture as the representative of the government has established various efforts through socialization, training and even the integration of the national character value (18 values) into the subjects taught in Elementary School, Junior High School and Senior High School.

The results of research from Hurtado \& DeAngelo (2012) show that the peer environment is a powerful, yet underutilized, tool for learning in college. Informal college experiences verify this, in those students who report discussing course content with peers outside of class demonstrates more changes in habits of mind activities than students who do not.

We studied students' self-reported understanding of global, national, and local issues and problems, which we term "civic awareness," and also a scale that measures students' complex thinking for a diverse democracy, which focuses on knowledge and abilities. We report both outcomes here as two different measures to study student assessment of their own abilities and understanding of contemporary problems (Hurtado 2009) in (Hurtado \& DeAngelo, 2012). The purpose of Civic according to Malin, Ballard, \& Damon (2015) is Civic purpose as a sustained intention to contribute to the world beyond the self through civic or political action, integrating the components of motivation, civic activity, and future-oriented civic intention.

The integration of the values of national character in each subject is necessary due to the awareness that the problems on national character turn into an urgency at this educational level. The young generation are expected to contribute their active participation in every aspect of life, and they will take part in the development of Indonesia when Indonesia celebrates its centennial Independence Day in 2045. However, the efforts of the government to instill the necessity of character building to improve the values of national character which seem to be decadent have not been so fruitful.

The problems lingering in the education aspect in Indonesia seem to be the urgent matters to solve. These 
problems are rooted in qualified human resources who become the teachers and the overall education system. The low competence of those teachers is assumed to be the main cause of the low quality of education. This vicious cycle leads to the low quality of human resources (students) who have graduated from the schools. (Sagala, 2009:21) explains that teacher can be simply defined as a person who delivers knowledge to students. The duty in transferring knowledge increases the image; in addition, teachers are inevitably important for the society. Therefore, there will be no doubt among the society regarding of the urgency of teachers for students. The society put their trust on teachers to teach students to be well-mannered, well-educated, intelligent and have good personality. (Sagala, 2009:iii) further explains that education refers to collaborative efforts which run within certain life pattern and can be classified into mechanic system and organic system. The mechanic system perceives education as the process which involves input-process-output and has direct and linier causal relationship. It implies that intervention aiming at achieving certain output can be designed to manipulate input. The education process contains various inputs such as students, teachers, curriculum, teaching materials, learning process, classes, building, equipment and environment. Thus, the mechanic system argues that the quality of output can be enhanced by increasing or decreasing the quality of input.

To improve the quality of teachers, the government has initiated certification program and competence test for teachers since past few years. Law No 14/2005 about 'Teachers and Lecturers" and Regulation of The Ministry of National Education No 16/2007 about "The Standard of Academic Qualification and Teacher Competences” have clearly mentioned that teachers must have four (4) competences, which are pedagogical competence, personality competence, social competence, and professional competence. The main objective of this program is to test competences for teachers who teach at the schools in order to be professional teachers. However, the lingering problems in education sector in Indonesia do not only concern about the low teacher competence but also the inadequate skill of teachers in the good class management. Teachers are still unable to well manage teaching activities which include students, curriculum, teaching material, classes, school environment and others.

Civic Education is one of the subjects taught in Elementary School, Junior High School and Senior High School. This subject directly or indirectly becomes the black sheep for the emergence of problems in Indonesia such as corruption, collusion, nepotism, mafia justice and others. Teachers of Civics thus become the integral part of the existing problems. The facts prove that teachers who teach Civic Education at schools have not attained the desired competences. Many of them do not understand how to teach Civic Education and manage the learning process either. These facts do not fulfill the expectation. Law no 14/2005 on 'Teachers and Lecturers' Article 1 Point 1 explains that 'teachers are professional educators whose main duties are to educate, teach, guide, assist, train, assess, and evaluate students who involve in early age education through formal, elementary, and secondary education.” According to Malin et al., (2015), key contributors to the development of civic purpose were: identity salience, beliefs and values, and invitation from one or more adults.

Based on the explanation above, the researcher puts the interest in the Students' Civic Disposition through Civics Learning and Teachers' Pedagogical Competence in High School. After identifying the problems, the researcher formulates research problems as follows: (1) What is the influence of Civics Learning on the improvement of students' civic disposition in SMA Negeri 1 Kawangkoan; (2) What is the influence of teachers' Pedagogical competence on the improvement of students' civic disposition in SMA Negeri 1 Kawangkoan; (3) Do Civics Learning and Teachers' Pedagogical Competence have significant influence on the improvement of Students' Civic Disposition?. The main objectives of this research are (1) to elaborate the influence of Civics Learning on the improvement of students' civic disposition in SMA Negeri 1 Kawangkoan; (2) to elaborate the influence of teachers' pedagogical competence on the improvement of students' civic disposition in SMA Negeri 1 Kawangkoan; (3) to figure out the significant influence of Civics Learning and Teachers' Pedagogical Competence on the improvement of Students' Civic Disposition.

\section{Literature Review}

\subsection{The Development of Civics in Indonesia}

Wahab \& Sapriya (2011:290) explained that the historical records of Indonesia have shown that traditional formal education had been prepared as the efforts to educate the citizen within the framework of national goals. The government had prepared to integrate social sciences into the curriculum. The terms used for civics along with the development and political course which Indonesia has undergone indicate the effort from the government.

According to the Department of Education and Culture (1962) as having been quoted by Budimansyah (2010:113-114), the development of Civics in Indonesia began when Civics was integrated into the curriculum in High School in 1962. This subject contained the material about the Indonesian government based on the 1945 Constitution. Moreover, Somantri (1976:7) explained that previously Civics contained the learning experiences which were compiled and selected from various subjects such as history, geography, economics, politics, the presidents' speeches, human rights declaration and knowledge about The United Nations. The term 'Civics' was not formally found in either 1957 Curriculum or 1946 Curriculum. The state structure and legal structure which discussed the concept of citizenship particularly on the legal status of 
citizens and the citizenship requirements (Somantri, 2001). In 1946 Curriculum, a subject on general knowledge which also explained the government system was included. In 1968 and 1969 curriculums, the term 'civics' and 'citizenship education' were interchangeably used. In the 1968 curriculum for elementary school, the term 'citizenship education' was the name of subject taught in which the history of Indonesia, the geography of Indonesia and civics (translated as knowledge on citizenship) were included. In the 1968 curriculum for Junior High School, citizenship education was the subject which discussed the history of Indonesia and constitutions including the 1945 Constitution. In the 1968 curriculum for Senior High School, citizenship education mainly discussed the 1945 Constitution. In the 1969 curriculum for Teacher Education School, citizenship education mainly concerned for the history of Indonesia, constitution, society and human rights (Department of Education and Culture (Dept. P\&K 1968a; 1968b; 1968c; 1969).

The amendment of 1968 School Curriculum into 1975 Curriculum was signified by the integration of some subjects into one subject. As a result, the subjects related to Pancasila (the Five Principles) and the 1945 Constitution were no longer assimilated into history, geography, and economics. The discussion of Pancasila (the Five Principles) and the 1945 Constitution becomes the subject of Moral Education. History, Geography, and Economics that were integrated into Social Sciences which were well known also as social studies. These changes were still valid as the 1984 Curriculum was established as the curriculum which had been adjusted. Due to changes within the aspects of life in Indonesia, Moral Education was revised. Based on various consideration, the revision of this subject was finalized with the implementation of the 1994 Curriculum. Moral Education was revised into Pancasila and Civic Education referring to Law of the Indonesian Republic No 2/1989 on National Education System (Wahab \& Sapriya, 2011:297-298). With the implementation of Law on National Education System No.20/2003, Pancasila and Civic Education was revised into Civics.

\subsection{Civics Learning in High School}

It can not be denied that the first and foremost goal from Civics is to be good and smart citizens. Winataputra (2001) explains that in Indonesia, Civics in the term of citizenship education is substantially and pedagogically designed to achieve goal to be good and smart citizens in all education levels. Winataputra \& Budimansyah (2007:73), explain that Civics has been the inherited part from the instruments and the practice of national education in five aspects:

First, as the subject taught in schools. Second, as the subject taught in universities. Third, as the branch of knowledge in social science within the framework of teacher education program. Fourth, as the program of political education in the form of Upgrading Course on the Directives for the Realization and implementation of Pancasila (P4) or other programs which are managed by the government as the crash program. Fifth, as the conceptual framework in individual's point of view and scholars' opinion. This eventually is developed as the underlying fundamental and point of view related to civics in the first, second, third, and fourth status.

Nu'man Somantri (2001) quoted by Wahab \& Sapriya (2011:312) delineates that the objectives of Civics should be further explored in 7 curricula covering (1) Science which includes facts, concepts and generalization; (2)Intellectual skill, from simple to complex skills, from investigation to credible conclusion, from critical thinking to creative thinking; (3) Attitude which includes virtues, awareness, and feeling; (4) Social skill.

According to Wahab \& Sapriya (2011:315), in the curriculum development system for education nowadays, the main objective of Civics refers to the standard for Civics content as explained in the appendix of Regulation of the Ministry of National Education No 22/2006. The objective of Civics is applicable in Elementary School, Junior and Senior High School. The main goal is oriented to the development of students' competence/skill which must be adjusted to the mental and intellectual, emotional and social development. Therefore, the objectives of Civics mainly focus on shaping students to acquire following skills:

1. To have critical, rational and creative thinking in giving response on the citizenship issues.

2. To take active participation, to be responsible and to take smart action on the activities in society and nation. Further, students must have anti-corruption attitude.

3. To have positive and democratic development based on the characters of Indonesian people to establish harmonious relationship with other nations.

4. To have indirect and direct interaction with other nations in the international scope by utilizing information technology and communication.

Civics has the vision 'to design a subject as the effort to shape nation and character building and the empowerment of people'. The attempt for shaping nation and character building is the characteristic and the noble idea of Civic Education. Meanwhile, the mission of Civic Education is 'to be good citizens. It means that the citizens are able to perform their rights and obligation based on political, legal and moral consciences'.

Learning can be defined as a system or process to educate students/learned which has been systematically designed, implemented and evaluated, so the students are able to achieve learning objectives in the efficient and effective ways (Komalasari, 2011:3). Based on the definition of learning, the explanation on the learning components will be elaborated as follows:

\subsection{Teachers' Pedagogical Competence}

Competence constitutes knowledge, skills, basic virtues 
and attitude reflected in thinking pattern and action (Mulyasa, 2002:37-38). Mc.Ashan explains that competence is defined as skills, knowledge, and capability which someone has acquired and has embedded as one unity; thus, a person is able to conduct cognitive, affective, and psychomotor attitudes (Mulyasa, 2002:38). Department of National Education (2004) defines competence as knowledge, skills, attitude, and virtues embodied in way of thinking and behaviour. To sum up from various definitions above, competence refers to students' capability to perform various conducts which reflect three aspects (cognitive, affective, and psychomotor ). A consistent and sustainable way of thinking and behavioural pattern leads a person to acquire his/her competence. It implies that a person has skills, knowledge, and basic virtues to conduct action.

Saud (200944-45) explains that there are 3 terms in English Language which contain the definition of competence.

1. "competence (n) is being competent, able(to do the work)"

2. "competent (adj.) refers to (persons) having ability, power, authority, skill, knowledge, etc. (to do what is needed)"

3. "competency is rational performance which satisfactorily meets the objectives for a desired condition”

The first definition explains that competence refers to skills or capability to do work. The second definition further explicates that competence generally refers to characteristics of competent people which consist of having ability, power, authority, skill, knowledge, and etc to do what is needed. The third definition explains that competence is rational performance which satisfactorily meets the objectives for a desired condition

Law No 14/2005 about 'Teachers and Lecturers" and Regulation of The Ministry of National Education No 16/2007 about 'The Standard of Academic Qualification and Teacher Competences have stipulated that a teacher must acquire 4 competences; those are pedagogic competence, personality competence, social competence, and professional competence. Pedagogical Competence is the ability to manage learning process for students. Personality Competence refers to the ability to have excellent, virtuous, and wise personalities. Teachers must have authority and become the good role model for students. Professional Competence is the ability to master the subjects taught comprehensively. Social Competence is the ability of teachers to establish effective and efficient communication and interaction with students, other teachers, students' parents and society.

\subsection{Students'/Citizens' Competence}

Thomas Lickona introduces the objectives of education in the effort to be smart and good citizens. Those objectives must be achieved through following processes: (1) Civic Knowledge; (2) Civic Disposition, dan (3) Civic Skill. Below is Diagram Venn which explains the correlation of each competence.

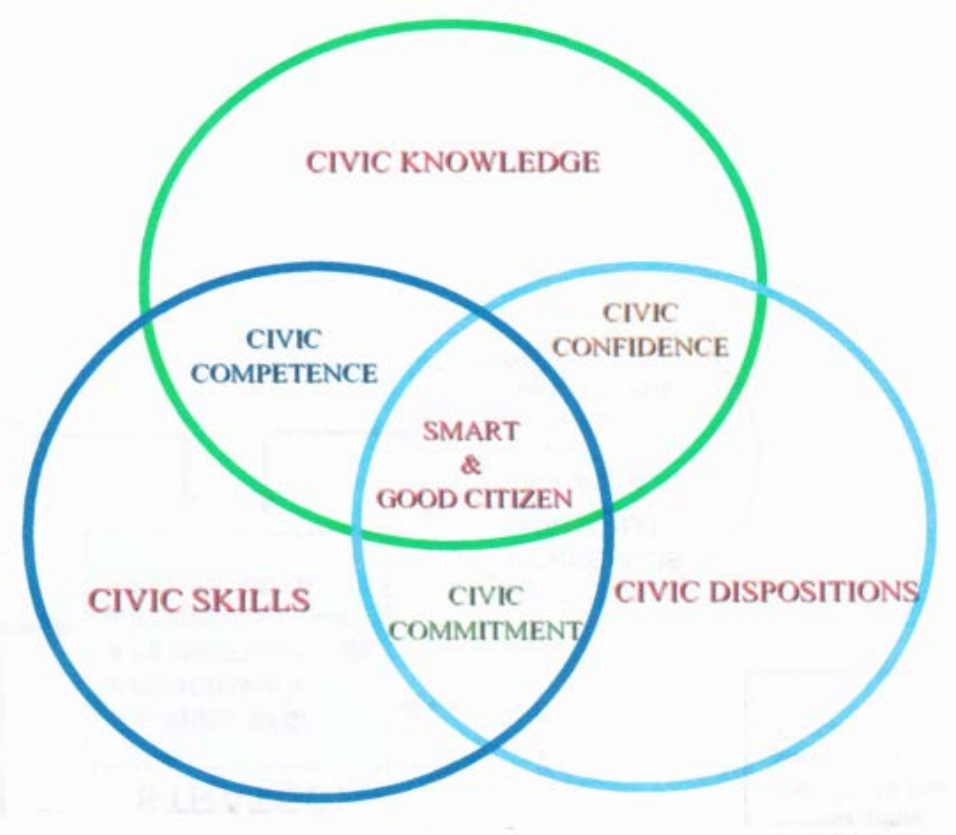

Figure 1. CCE’s Seven Core Elements of Civic Education (CCE; 1996; Winataputra, 2001) 
Branson (1998) has classified civic competence into 3 categories: (1) Civic knowledge which is related to knowledge which citizens should know; (2) Civic skill, relevant intellectual and participatory ability of citizens; (3) Civic disposition which signifies that public and private characters are important for maintaining and developing constitutional democracy.

Civic knowledge refers to substantial material which every citizen must know about their rights and obligations. This knowledge provides basic explanation on the political system and structure, and ideal social system and government which should be well-implemented in the life of people. It also contains universal values in democratic society and efforts to achieve mutual development and harmonious relationship with the global society.

Civic skill is developed from civic knowledge which primarily aims at attaining useful and meaningful knowledge to solve problems in the life of society and nation. Civil skills consist of intellectual skills and participation skills.

Civic disposition implies that public and private characters are important for maintaining and developing constitutional democracy. As civic skills, civic disposition also grows gradually due to what a person has learned and experienced at home, school, community and civil society organizations. These experiences are expected to sharpen the awareness that democracy requires independent government to be responsible for all individuals. Private characters such as moral responsibility, self-discipline and respect for human dignity must be developed. Public character is also important. Awareness of the citizens, hospitality, obedience of rule of law, critical thinking and willingness to listen, negotiate and compromise are important dispositions to undergo the desired democracy (Branson, 1998).

\section{Methodology}

The research location is SMA Negeri 1 Kawangkoan-Minahasa, and the research population is all students. The samples of this research are the students of class XI A and XI B. This research uses quantitative approach because all research data are in the form of numbers and the researcher performs statistical analysis. Research methodology is a survey method in which the research attempts to interpret numbers to describe inclinations, behaviors, or opinions of certain population by analyzing population samples. Data collecting techniques used in this research are questionnaire, interview and literature review. Data which have been collected by using instruments having met validity requirement and ideal realibility are processed and analyzed. In processing and analyzing data, the researcher uses computer assistance to operate SPSS (Statistical Product and Services Solution) version 19.

\section{Results and Findings}

\section{a. The influence of Civics Learning on the Development of Students' Civic Disposition}

The result of the research shows that Civics Learning variable has significant influence on the development of students' Civic disposition. This result supports the notion of Department of National Education (2003:7) which delineates that "Civic Education is a subject focusing on self-improvement from various aspects such as religion, socio culture, language, age, and tribes to be smart, skillful, and have strong character embedded in Pancasila and the 1945 Constitution'. Komalasari (2011:88) argues that the core essence of Civic Education is value-based education. Thus, Civic education relies heavily on the development of values, morality, and behavior of students. Supporting the previous notions, Budimansyah and Suryadi (2008:68) denote that Civic Education is one of subjects which carries national mission to educate the Indonesia people by upholding 'value-based education'. Therefore, this subject must be well-designed. Configuration or systematic framework of Civic Education is established based on following paradigms: First, Civic Education is designed as a course which aims at developing individual potency to be noble, smart, participatory, and responsible Indonesian citizens.

Table 1. The Summary of Hypotheses Test Result

\begin{tabular}{|c|c|c|c|c|}
\hline No & Hypotheses & Statistical Test & Result & Conclusion \\
\hline \multirow{2}{*}{1} & Civics Learning $\left(\mathrm{X}_{1}\right)$ has significant influence on Students' Civic \\
& Dispositions $(\mathrm{Y})$ & $\begin{array}{c}\mathrm{Ho}: \beta_{1} \leq 0 \\
\mathrm{H}_{1}: \beta_{1}>0\end{array}$ & $\begin{array}{c}\text { Ho is } \\
\text { rejected }\end{array}$ & $\begin{array}{c}\text { Having positive and } \\
\text { significant influence }\end{array}$ \\
\hline \multirow{2}{*}{2} & Teachers' Pedagogical Competences $\left(\mathrm{X}_{2}\right)$ has significant influence \\
& on Students' Civic Dispositions $(\mathrm{Y})$ & $\begin{array}{c}\mathrm{Ho}: \beta_{2} \leq 0 \\
\mathrm{H}_{1}: \beta_{2}>0\end{array}$ & $\begin{array}{c}\text { Ho is } \\
\text { rejected }\end{array}$ & $\begin{array}{c}\text { Having positive and } \\
\text { significant influence }\end{array}$ \\
\hline \multirow{2}{*}{3} & $\begin{array}{c}\text { Civics Learning }\left(\mathrm{X}_{1}\right) \text { and Teachers' Pedagogical Competences }\left(\mathrm{X}_{2}\right) \\
\text { have significant influence on Students' Civic Dispositions }(\mathrm{Y})\end{array}$ & $\begin{array}{c}\mathrm{Ho}: \beta_{3} \leq 0 \\
\mathrm{H}_{1}: \beta_{3}>0\end{array}$ & $\begin{array}{c}\text { Ho is } \\
\text { rejected }\end{array}$ & $\begin{array}{c}\text { Having positive and } \\
\text { significant influence }\end{array}$ \\
\hline
\end{tabular}


Second, Civic Education is theoretically designed as a learning subject which explores cognitive, affective and psychomotor dimensions. These dimensions are confluent; in other words, they are integrated into the substances, ideas, values, concepts, and morality embodied in Pancasila, democratic citizenship, and national defense. Third, Civic Education is programmatically designed as a learning subject which emphasizes content embedding values and learning experiences. These two goals must be embedded in various behavior in daily life of the Indonesian citizens. These also serve as the guidance for the citizens in undergoing the life in society, within the nation and with other nations. It can be said that these values are the further embodiment of idea, values, concepts and morality existing in Pancasila, democratic citizenship, and national defense. (Miles-Touya \& Rossi, 2016) findings are in line with the proposals of civic virtue theorists or grass movements who suggest that citizenship education should be included in the compulsory school curricula since, if not, families or local communities will only transmit their particular view of the world.

To sum up those opinions. Civics Learning primarily focuses on developing students' civic competences which eventually give influence on the development of students' Civic disposition. Branson, (1998) has classified civic competence into 3 categories: (1) Civic knowledge which is related to knowledge which citizens should know; (2) Civic skill, relevant intellectual and participatory ability of citizens; (3) Civic disposition which signifies that public and private characters are important for maintaining and developing constitutional democracy.

Civic knowledge refers to substantial material which every citizen must know about their rights and obligations. This knowledge provides basic explanation on the political system and structure, and ideal social system and government which should be well-implemented in the life of people. It also contains universal values in democratic society and efforts to achieve mutual development and harmonious relationship with the global society.

Civic skill is developed from civic knowledge which primarily aims at attaining useful and meaningful knowledge to solve problems in the life of society and nation. Civil skills consist of intellectual skills and participation skills.

Civic disposition implies that public and private characters are important for maintaining and developing constitutional democracy. As civic skills, civic disposition also grows gradually due to what a person has learned and experienced at home, school, community and civil society organizations. These experiences are expected to sharpen the awareness that democracy requires independent government to be responsible for all individuals. Private characters such as moral responsibility, self-discipline and respect for human dignity must be developed. Public character is also important. Awareness of the citizens, hospitality, obedience of rule of law, critical thinking and willingness to listen, negotiate and compromise are important dispositions to undergo the desired democracy (Branson, 1998).

\section{b. The influence of Teachers' Pedagogical Competences on the Development of Students' Civic Disposition}

Law No 14/2005 about "Teachers and Lecturers" and Regulation of The Ministry of National Education No 16/2007 about 'The Standard of Academic Qualification and Teacher Competences have stipulated that a teacher must acquire 4 competences; those are pedagogical competence, personality competence, social competence, and professional competence. Pedagogical Competence is the ability to manage learning process for students. Personality Competence refers to the ability to have excellent, virtuous, and wise personalities. Teachers must have authority and become the good role model for students. Professional Competence is the ability to master the subjects taught comprehensively. Social Competence is the ability of teachers to establish effective and efficient communication and interaction with students, other teachers, students' parents and society.

Civic disposition implies that public and private characters are important for maintaining and developing constitutional democracy. As civic skills, civic disposition also grows gradually due to what a person has learned and experienced at home, school, community and civil society organizations. These experiences are expected to sharpen the awareness that democracy requires independent government to be responsible for all individuals. Private characters such as moral responsibility, self-discipline and respect for human dignity must be developed. Public character is also important. Awareness of the citizens, hospitality, obedience of rule of law, critical thinking and willingness to listen, negotiate and compromise are important dispositions to undergo the desired democracy (Branson, 1998).

\section{c. The Influence of Civics Learning and Teachers' Pedagogical Competences on the development of Students' Civic Dispositions}

Based on the result of hypotheses test, it can be summed up that civics learning and teachers' pedagogical competence have influence on the students' Civic Dispositions. A well-designed Civics learning has a competence which improves students' Civic dispositions which refer to the refinement of students' private and public characters. According to National Standards for Civics and Government as quoted by Branson (1998), private and public characters constitute:

1. An independent citizen. This character covers self-awareness to be a responsible individual who is obedient to rules. This obedience is not performed due to external force or supervision. This character also covers taking responsibility for consequences due to any actions taken and fulfilling moral and legal obligation as the democratic citizen,

2. Fulfilling responsibility as a citizen in economic and political aspects. This responsibility covers taking care of ourselves, earning money for family and taking care of family, educating and nurturing children. It also includes keeping up with public issues, voting, paying 
tax, becoming witness in court, taking part in community activities, and sharpening their leadership skill.

3. Giving respect to the dignity of each individual. Showing respect to others can be seen from following activities; listening to their opinion, showing politeness, upholding the rights and needs of other citizens, and obeying the principles of the majority and giving respect to the opinion of the minority.

4. Participating in citizenship activities wisely and effectively. It implies that a person must keep up with the newest information before voting or taking part in public debate. A citizen must follow the discussion by maintaining a good attitude and serious attention. Further, a citizen must be able to evaluate when she/he has to put their personal interest aside in order to achieve public goals. He/she also evaluates when declining certain citizenship activities due to obligation or constitutional principles. This character refers to the citizen dispositions which support their participation on public activities.

\section{Conclusions}

Based on the result and discussion, the researcher comes to some concluding remarks as follows; First, Civics Learning has positive influence to Civic disposition of students in SMA Negeri 1 Kawangkoan. It means that Civics Learnings enables students to develop their Civic Disposition. Second, teachers’ pedagogical competence has positive influence to Civic disposition of students in SMA Negeri 1 Kawangkoan. It means that better teachers' pedagogical competence will result in better Civic Disposition of students. Third, Civics Learnings and teachers' pedagogical competence have positive influence to Civic disposition of students in SMA Negeri 1 Kawangkoan. It means that the materials of civics learning and good teachers' pedagogical competence lead to better Civic Disposition of students.

\section{REFERENCES}

[1] Branson, M. S. (1998). The role of civic education: A forthcoming Education Policy Task Force position paper from the Communitarian Network. Center for Civic Education.

[2] Budimansyah, D. (2010). Penguatan pendidikan kewarganegaraan untuk membangun karakter bangsa. Bandung: Widya Aksara Press.

[3] Hurtado, S., \& DeAngelo, L. (2012). Linking Diversity and Civic-Minded Practices with Student Outcomes. Liberal Education, 98, 14.

[4] Komalasari, K. (2011). Pembelajaran Kontekstual, Konsep dan Aplikasi, Kualitatif, dan R \& D. Bandung: Alfabeta.

[5] Malin, H., Ballard, P. J., \& Damon, W. (2015). Civic purpose: An integrated construct for understanding civic development in adolescence. Human Development, 58(2), 103-130. https://doi.org/10.1159/000381655

[6] Miles-Touya, D., \& Rossi, M. (2016). Cultural transmission of civic attitudes. SpringerPlus, 5(1), 949. https://doi.org/10.1186/s40064-016-2616-4

[7] Mulyasa, E. (2002). Kurikulum Berbasis Kompetensi: Konsep, Karakteristik, Dan Implementasi Bandung: PT. Remaja Rosdakarya (Vol. 112).

[8] Sagala, S. (2009). Kemampuan profesional guru dan tenaga kependidikan. Bandung: Alfabeta.

[9] Saud, U. S. (2009). Pengembangan Profesi Guru. Bandung: Alfabeta.

[10] Somantri, M. N. (1976). Metode mengajar civics. Erlangga, Jakarta.

[11] Somantri, M. N. (2001). Menggagas pembaharuan pendidikan IPS. (D. Supriadi \& R. Mulyana, Eds.). Bandung: Remaja Rosdakarya.

[12] Wahab, A. A., \& Sapriya. (2011). Teori dan landasan pendidikan kewarganegaraan. Bandung: Alfabeta.

[13] Winataputra, U. S. (2001). Jatidiri Pendidikan Kewarganegaraan sebagai wahana sistemik Pendidikan Demokrasi (Suatu kajian konseptual dalam konteks Pendidikan IPS). Universitas Pendidikan Indonesia, Bandung.

[14] Winataputra, U. S., \& Budimansyah, D. (2007). Civic education: Konteks, landasan, bahan ajar, dan kultur kelas. Bandung: Program Studi Pendidikan Kewarganegaraan SPS UPI. 